\title{
Decolonizing education: Re-schooling in India
}

\section{Educación descolonizadora: reescolarización en la India}

NAVNEET SHARMA*

SHOWKAT AHMAD MIR*

The industrialization and its consequential imperialism and colonialism have impacted this world for three centuries. India has been a colony of the British Empire for two centuries. These eventful two centuries of Indian history did see the influence of not only the political and economical might of the "great" Britain, but its influence on every milieu of Indian life. India's indigenous education system was gradually displaced and the colonial model of education pervaded under the patronage from the colonial-state. The language, pedagogy, evaluation and knowledge of the colonizer became naturalis obligato for the population of the colony. India got independence in 1947 and took to the task of decolonizing education immediately. The attempts to decolonize education from various standpoints of political activism, universalism and religious nationalism are charted in this article. What decolonizing education should entail and how India has responded to this question in the last century and how the neo-liberal order has supported a particular ideology to have a dominant say in this process are concerns of this article. We analyse how re-schooling and indoctrination are projected as the most nationalist response for methodical decolonizing of education.

La industrialización, y el imperialismo y colonialismo que trajo consigo, ha tenido impacto en el mundo. En el caso de la India, esta se convirtió en una colonia del imperio británico durante dos siglos, periodo en el cual no solo predominó la fuerza política y económica de la "Gran" Bretaña, sino su influencia en cada espacio de la vida indígena. El sistema de educación indígena fue desplazado poco a poco y el modelo colonial de educación se extendió bajo el resguardo del Estado colonial. El lenguaje, la pedagogía, la evaluación y el conocimiento del colonizador fueron impuestos a la población hasta 1947, año en que la colonia se independizó y emprendió la tarea de descolonizar la educación. En este artículo abordamos los intentos de descolonizar la educación desde varias perspectivas del activismo político, el universalismo y el nacionalismo religioso. Qué implica descolonizar la educación, cómo la India ha respondido a esta cuestión y cómo el orden neoliberal ha promovido una ideología específica para dominar el proceso de descolonización educativa son los ejes que guían nuestro trabajo. Los resultados revelan que la reescolarización y el adoctrinamiento se proyectan como una respuesta más nacionalista para una descolonización metódica de la educación.

\section{Keywords:}

decolonization, re-schooling, indoctrination, education, saffronisation

Submitted: September 3, 2018.| Accepted for publication: February 11, 2019. Recovered from: https://sinectica.iteso.mx/index.php/SINECTICA/article/view/913 DOI: 10.31391/S2007-7033(2019)0052-007

\footnotetext{
* Assistant Professor in Department of Teacher Education, School of Education, Central University of Himachal Pradesh, Dharmashala, India. His research interests are philosophy of education, educational theory and social science education. E-mail: navneetsharma29@gmail.com

${ }^{* *}$ He is pursuing PhD from Department of Teacher Education, School of Education Central University of Himachal Pradesh, Dharamshala. He has post-graduate degree in Education from Central University of Jammu, India. He is working on his doctoral thesis on Knowledge, Schooling and Education in Kashmir: A study of state in crisis and conflict.E-mail: showkatmir09@gmail.com
} 


\section{INTRODUCTION}

The advent of industrialization and its consequential imperialism and colonialism overshadowed the history of human civilization for three centuries. This onslaught began in the seventeenth century and continued till early twentieth century. This was not only a commercial and political entrapment of the colonies and the colonized but was also an extension of socio-cultural hegemonic dominance. The socio-cultural milieu of the colonized got overawed by the seemingly progressive European modernity. Education, it's process and institutionalization were also influenced by the political economy of the colony and the colonizer. The indigenous knowledge and ways of knowing were characterized as brute, un-progressive and the reason for economic and cultural backwardness. The process of 'decolonization' describes one of the most fundamental historical developments of the twentieth century. At the beginning of the last century, a few European empires ruled over a great part of the earth's surface and, thereby, a very large percentage of the world population. The world was ruled over by few European countries, the 'great' Britain being the biggest colonizer as the adage was -The empire on which the sun never sets- was to reflect the vastness of the geography controlled by Britain.

When the twentieth century came to an end, the world had transformed beyond recognition, with long freedom struggles almost 150 nation-states got their independence and became part of the United Nations as full and equal members. This transformative process called decolonization is now an important field of analytical study but there is as yet no consensus about what it really entails. Arguably, there are many descriptions of decolonization and every author ultimately has to decide how to define decolonization. As Bismarck (2012) writes, “... there is the traditionalist definition of decolonization as a process by which legally dependent territories obtained their constitutional independence and entered the world stage of international relations as sovereign states."

This kind of transition was symbolized by these countries in the form of designing their own flags, composing new national anthems and joining the United Nations as full and equal members. While this definition of decolonization at first appears to be lucid and useful in its pragmatic thought, it is also quite narrow. By concentrating exclusively on constitutional change and the political reasons behind it, it excludes the economic, social, cultural and educational implications of this transformative process. Alternatively, there is the possibility of seeing decolonization as the reversal of the process of European imperial expansion with all its political, economic, social, cultural and linguistic consequences.

This definition is methodologically advantageous because it allows for the analysis of both -territories and developments- that a strictly constitutional view neglects. It enables us to analyse and study the social, cultural, economic and educational implications of its end. However, the problem with this approach is that in the final analysis it implies, "that a territory has only been decolonized when it has been purged of every remnant of its colonial past" (Bismarck, 2012). It seems convincing as in consequence the European expansionism has transformed the world over a period of almost 500 years and left a distinct imprint on large parts of Africa, Asia, and the Middle East. Possibly the most noticeable lasting legacy of European imperialism is the spread of languages like French, Spanish, and especially English throughout the 
world but to argue that decolonization will only be complete once this imprint has been removed in its entirety from the countries/places ever colonized stretches the definition of the term to an extent stripping it of its analytical use.

Alfred (2009a) argues: "Decolonization can only be achieved through the resurgence of an indigenous consciousness channelled into contention with colonialism." There can never be such a thing as a clean slate when it comes to decolonization. Given the numerous methodological traps of studying decolonization, finding the right balance between a too narrow and a too wide definition is not easy. One possible way out of this dilemma is to analyze the subject within a larger context, instead of concentrating exclusively on the relationship between the motherland (colonizer) and its dependent territory (colony). This holds true for the key period of decolonization during the three decades after the Second World War, when the majority of colonies worldwide gained their independence (at least constitutionally). To understand decolonization, one has to remember above anything else that it was a global phenomenon. And in its end its imprints are still obvious.

\section{DECOLONIZING EDUCATION}

Decolonization is opposite to colonial ways of thinking and acting. It demands an indigenous starting point and an articulation of what decolonization means for indigenous peoples of different countries. The breakdown of Western empires and the entry of non-Western states into the international states system was one of the most gigantic political processes of the twentieth century (Sium, Desai \& Ritskes, 2012). When a colony achieves political independence, one of the many tasks it subsequently takes upon itself is towards the 'decolonization' of its educational culture.

Elder (2018) argues, "Decolonization characteristically includes rewriting the curriculum and syllabi, if only to bring about the minimum of changing the "law-breaking insurgents' to the 'nation's heroes' in the struggle for independence." Gandhi rightly observes that colonial education is a citadel of slavery that denies learners object lessons in liberty and self respect (Adjei, 2007). Gandhi's decolonizing process of education aimed to develop a system of education that facilitates democratic life and economic self-sufficiency rather than one that perpetuates older systems of dependence and inequity -a challenge faced by contemporary India even more-. The modern European education and schooling was perceived as empowering and liberating.

In this article we attempt to map India's response with respect to colonial education project. India has a history of long freedom struggle of almost hundred years and achieved political freedom in 1947. Confrontation towards colonial education in India began in early twentieth century. The responses to colonial education and vehement opposition to it in India can be largely categorised into three. One, which comes from educational thinker and philosopher Rabindra Nath Tagore, where he calls upon to confront colonialism not by nationalism but by internationalism -"Where the mind is without fear, and the head is held high, Where the world is not broken up into fragments by narrow domestic walls...".

The second response which evolved out of political resistance to colonialism was from Gandhi where he attempts to counter colonial education by Nayi Talim (New Education) which was to help the colonized citizen achieve economic and political 
liberty. The third response came from the values and mores of religion where religious education was seen as an indigenised response to colonial education. Post independence, the desire of the Indian nation to be in the super power leagues or to be counted as developed country led it to imitate colonial education model all over again. Gandhi's Nayi Talim and Tagore's Universalism were relegated to the periphery in India's approach to re-modelling education and were left to certain individuals/institutions to conserve them as relic. The neo-liberal order of the economy and political empowerment of the people refurbished the agenda of nationalism.

In this article, we mapp how nationalistic education is seen as the only legitimate response to the decolonization of the minds of the people. This article emphasises that nationalization and/or Indianization of education retains the colonial structures, institutions and pedagogy of colonial model of education and only attempts to bring the change into the curriculum. Moreover, this article underlines that the process of reschooling is more about indoctrination into a particular ideology, rather than promoting and supporting the inquisitiveness and the rationality of the essentially argumentative Indian.

Decolonizing education has it's own quagmires and dilemmas which every erstwhile colony-nation has to face. The attempt to move away from the shackles of colonial influence on cultural and social milieu has it's own challenges. The colonial model of education can be credited for that it was the influence of the English/European education which instilled the idea of nation/nationalism in the populace of its colonies. It was influence of the English/European education systems that made people deride the social evils. In the Indian scenario, the practice of 'sati' (widow burning on the pyre of the husband) gets abolished, widows got the right to remarry, child marriage was abolished and the access to schooling and education became available to everyone irrespective of the class, caste, colour, creed and gender. It was the influence of this modern education that people could appreciate differences and diversity among themselves and could believe in the idea of 'unity' as 'citizens' of the nation. Though this turned out to be counter-productive to the agenda of colonialism-people came together and sought freedom from the colonizers and their imperialistic mechanisations.

The intent of the English/European education system was far away from unification. It was to produce civic, loyal citizenry and bureaucracy which will facilitate the rule of colonizer. It aimed to produce people who are native/indigenous but would be alike their rulers in thought and action. Macaulay in his infamous speech called 'Macaulay's minutes on education in India' emphasised that education would produce citizens which would be brown (sic) in colour but will be English in thought and action. Moreover this was to legitimize 'downward filtration' theory where knowledge was supposed to flow from selected few civilized higher ups to all the brute and uncultured natives. It further legitimized the relationship between schooling and economic mobility as those who could speak and write the colonizers' language were accommodated in government jobs and thus were 'alienated' from their own culture and country-men.

After gaining political independence from their respective colonizers, the erstwhile colonies spent a lot of energy in decolonizing the mind, body and spirit of it's people and to instil national pride. These colonies also suffered from the strife of the 
imperial policy of 'Divide and Rule'. The Indian sub-continent did see the communal and religion-based division; and the geography and demography became the basis for creation of countries like Pakistan and Bangladesh. These independent countries now wishing to instil national pride in its citizenry looked up to the education system. The call for unity amongst citizens to fight and grow had to look for different 'villains' once the colonizers left. So these countries and their polity had no option but to see and project each other as enemies to keep the nationalist pot stirring and boiling. The education system also suffered this quagmire as it had been tasked to instil national pride while simultaneously teaching harmony and peaceful relations with fellow/neighbouring nations.

In India, the first two decades post-independence witnessed emphasis laid on learning science and technology to help the nation grow. India is probably the only nation which has put the 'scientific temperament' as one of the directive principles in its constitution. The western economic and social growth model was imitated without a speck of scepticism. The institutions of higher learning in science, engineering and technology grew at a rapid pace even at the cost of universalization of primary education. These institutions were hailed as harbingers of modern era and growth and technology marvels were hailed as 'temples' of modern India. The science which became the talisman for growth was western science and was the one which evolved and originated with European modernity and the renaissance. The native science/scientific method was frowned upon as a make-shift arrangement. Even the medicinal and health practices which were indigenous in nature were looked upon as crude, orthodoxical and uncouth and the western medicine system alone was hailed as science. The education system of India and other colonies got over-awed by the seemingly progressive uniform pedagogy and evaluation. Anyone who differed from this view was labelled as a crude aboriginal.

In Indian scenario, the caste strife deepened the divide and many caste leaders thought that colonial model of education was the only way to break away from sanskritic-hegemonic brahminical system of education. It was for these reasons that Gandhian response to colonial education by Nayi Talim got relegated to periphery in Indian Education system. The universalism and internationalism prophesied by Rabindra Nath Tagore became redundant with more frequent conflict with neighbouring countries. The Indian sub-continent did see many wars on full-fledged scales with India, Pakistan and China being at loggerheads. The idea of nation and nationalism was in such mess that internationalism and universalism could not make any influence on the Indian psyche which claimed once that whole of Earth is one family (Vasudhaiva kutumbakam-Universal brotherhood).

In India, one is struck by various visions and conceptions of decolonization and with its similarities or differences with saffronisation of education (saffronisation is an Indian political neologism named after saffron robes worn by Hindu ascetics, but is more of political ideology of hindutva in action). It is usually believed by exponents of Hindutva that theirs is a bold revolt against western hegemony, but in fact it is an imperfect and slavish imitation of that hegemonic system, a caricature. The agenda of decolonization somehow became the cornerstone of religious nationalism where upon minority communities (Muslims in case of India) are projected as the biggest hindrance in nation's growth. The practitioners of any other model of 
decolonization process were soon labelled as either true utopian or as anti-national. Mahatma Gandhi, Radhakrishnan, and other leaders of both the political and the cultural awakening of India before independence appear to speak in the same vein but the disturbing new trend is a narrowed, bigoted version of 'Spiritual Value', leaning explicitly on the Hindu heritage.

It is pertinent to mention here that the Indian Constitution bears the traces of a historical context of religious disagreement and conflict, and it comes down resolutely in favour of a broad, tolerant humanism. The preamble declares among its sacred goals 'liberty of thought, expression, belief, faith and worship'. The secularism implied by the Indian Constitution not only indicates non-discrimination among citizens on the basis of religion in matters of public employment, or in admission to state-funded educational institutions, or in the approach of public administration; it does not stop there. It goes on to commit itself to protecting the right of all religions.

Even K M Munshi, the orthodox Hindu leader, categorically insisted on inclusion of the Christian's right to proselytize. Yet, saffronisation of education is part of a farreaching agenda to maintain the historic trends. It actually harks back to the period of turmoil to which the secularism of the Constitution had been an answer. As if the road not taken then again faces the nation at a point to which it has returned in the course of its wanderings. However, the problem is not simply that of historical regression; what appears to be purely regressive is also determined in some way by larger contemporary development. Neo-colonialism today requires of its success the prevalence of feudal or semi-feudal ideas and practices. However, such elements, being out of step with the present, and failing to answer the genuine needs of the present, are bound to be overlaid with deliberate self-hypnosis, irrationality and savagery. In any case it is an over-simplification to say that it is only a question of reactionary revival and regression. The ideology that has hypnotized the masses drawn by the saffron crew had its genesis in early colonial times during the colonial transformation of Indian society, the introduction of modernity under colonial patronage.

The uncritical and fanatical worship of a chauvinist version of our past is a product of the same mind-set. And it is natural for such a mind-set to submit to the hegemony of neo-colonialism. How does colonialism continue to shape our consciousness? It manifests itself first in a lack of confidence in one's own creativity and a dependence on western centres of learning for the very conceptions of academic and cultural excellence. This mental dependence is also actively promoted by western powers for obvious reasons. Ours is a cruel dilemma as we can neither snap our link with the colonial type of modernity at one go, nor find answer to many of our present dilemmas in tradition but this hardly excuses a supine surrender to the poisoned charms of a reactionary solution from the past. There is an over-riding need for thorough revision of the structure of education all over the world.

The International Commission on Development of Education constituted with the world's leading educationists by the Unesco, stated in its report of 1972, "Education follows the laws of every human undertaking, growing old and gathering deadwood. To remain a living organism, capable of satisfying with intelligence and vigor the requirements of individuals and developing societies, it must avoid complacency and routine. It must constantly question its objectives, its contents and its methods." 
One of the problems the commission had warned all developing countries about had been the strong colonial traces in the present education systems of their countries. And just as the political and economic effects of colonialism are strongly felt today, most educational systems in Latin American, Asian and African countries mirror the legacy of a one-time mother country or of some other outside hegemony, irrespective of whether they meet the nation's present needs.

The legacy of colonialism in the system of education and conceptions about education in these unfortunate countries has been precisely summed up by Pieterse and Parekh (1995), they argued,

Although the effects of British colonialism on different aspects of Indian life and thought varied a great deal, and led to much critical self-questioning, colonial rule did distort India's understanding of its own past, present and future. It also weakened India's self-confidence and capacity to explore and experiment with alternative ways of life and thought. Above all, it encouraged heteronomy, the tendency to judge itself by western standards and to make western approval the basis of is self-respect and self-esteem, and especially among the modernists for whom the west represented almost all that they valued.

The way out of this predicament can be charted by the authors on following lines: "To be autonomous is to break through the categories of thought constructed by others, to think afresh and analyze one's predicament and make one's choices in terms one has rationally and independently arrived at." Fortunately for us, Pieterse and Parekh caution against rejecting modernity as it is "deeply inscribed in all areas of its life (or nation) and is integral to its identity" and advocate critical appropriation of its legacy in various fields so as to liberate the mind from the unconscious colonial constraints.

Colonialism had thus made over the inherited social and mental structures of traditional Indian society in a fairly drastic manner and in the process sapped the confidence and self-reliance of the native. It is usually believed by exponents of Hindutva that theirs is a bold revolt against western hegemony, but it is an imperfect and slavish imitation of that hegemonic system, a caricature. The continuity of the colonial class-structure into independent India reinforced, and was itself in turn reinforced by, Hindu chauvinism. In the meantime, the former revolutionary later acquiescent to British domination, V D Savarkar, invoked Hindutva as the basis of Indian nationalism, and the mentor of RSS in the 1950s and the 1960s, Guru Golwalkar, reiterated the same ideas in We, or Our Nationhood Defined. Then as now, the erroneous and fatal identification of the enemy has been the product of collusion between colonialism and native ruling elites.

\section{RESCHOOLING}

Alcoff (2014) argues: "Decolonizing education requires first and foremost a thorough and comprehensive critical analysis of colonialism itself, in all its subtle guises." As such, the starting point of decolonization is not a rejection of colonialism but by replacing the dominant with the marginalized, or as Fanon (1968) puts it, make it so "the last shall be first and the first last". The decolonizing approach seeks to re-imagine and rearticulate power, change, and knowledge through a multiplicity of epistemologies, ontologies and axiologies. Decolonization cannot take place 
without contestation. It must necessarily push back against the colonial relations of power that threaten Indigenous ways of being. Alfred (2009b) and others have suggested that decolonization can only be "achieved through the resurgence of an Indigenous consciousness channelled into contention with colonialism". As Said argued about European education system and emphasized that the main concern of the system was, "the power to narrate, or to block other narratives from forming and emerging, is very important to culture and imperialism, and constitutes one of the main connections between them."

In the words of 19th century British colonial official, the intention was to "form a class who may be interpreters between us and the millions we govern; a class of persons, Indian in blood and color, but English in taste, in opinions, in morals, and in intellect" (Spivak, 1988).

The purpose of the colonial educational model, in other words, was not only to prepare select individuals from the indigenous population to facilitate the economic exploitation of the colony, but to actually instil in them the norms and expectations of the colonizer, replacing the indigenous systems of reference with those relevant to the colonial power, and in India the emerging notion of education imitates back to European model. The whole notion of education in India is moving towards the creation of indigenous colonization, in the backdrop of current government which came at helm in 2014. Education is not about content, not just providing the right textbooks, syllabi/curriculum or creating ideal Bharatiya/Hindu citizens. Education is all about the processes employed during acquisition of knowledge as we learn to ask questions. In order to acquire these components, pedagogy is given the central facet in which the learner occupies the important place who eventually becomes free thinkers, reformers, change agents, interlocutors and iconoclasts.

The outcomes of any system of education ought to be premised as stated and enumerated. Modes are varying that is, localized/globalized/indianized, but certainly not Hinduized. In the name of "Hinduization", the Government of India and its paraphernalia such as RSS, (Rashtriya Swayamsevak Sangh -National Volunteers Organization-. A hindu outfit with authoritarian say in the present government) $B a$ jrang Dal, Hindu Mahasabha and other ultra-right outfits are desperate to introduce their curricula and Hindu brand of education by giving preference to select portions of history, eulogizing select individuals and thinkers, highlighting select historical events with glaring subjectivity by distorting certain facts, imposing particular languages such as Sanskrit and glorifying certain texts and discarding others -all of which are to be taken seriously because all these involve ideological and cultural inclination towards one particular world-view as against other world views thereby creating fanatical, clouded and frenzied mind-sets and thus preparing depraved minds in the form of cultural annihilators.

In 2007, the Chief Minister of Madhya Pradesh, Shivraj Singh Chouhan, removed sex education from the state curriculum on the grounds that it offended Indian values on the advice of Dina Nath Batra, who also suggested that yoga be added to the curriculum instead of sex education. This view was criticized by S. Anandhi, a scholar of gender issues, who wrote that sex-education was aimed at combating abuse; she also stated that fundamentalist organizations were attempting to repress 
sexuality. In June 2014, the Bharatiya Janata Party government of Gujarat issued a circular, declaring six text books written by Batra to be part of the state education curriculum as supplementary literature. Originally written in Hindi, the books were translated into Gujarati, and were released by Bhupendrasinh Chudasama, the former state education minister, who stated that they were compulsory.

Batra has indicated that the initiative for using the books came from the then Narendra Modi government in Gujarat and the books are found to carry a foreword from Modi. The books received severe criticism from historians as well as the popular press. Historian Romila Thapar stated that the books contained «not history, but fantasy". Irfan Habib, another prominent historian, described them as "hilarious but scary". He said that the books were being introduced as part of a political program. The process of decolonization which had to be culturally and socially transformative in nature remained political and ideological. The process which required social churning instead looked to overthrowing the insignias and symbols of colonialism. The process and decolonizing efforts took to turning back the clock. The educational processes, which required restructuring and reshaping of institutions, got struck with replacing, renaming and selective amnesia.

The debate about what decolonization should entail and what a decolonized education should aim forgot abandoned and rechristened national pride and nationalism took to superficial change in content and curriculum rather than emphasizing on indigenous learning practices and methods of knowledge construction. In the absence of the above discourse it was obvious that 'short-cuts' and shorter 'shortcuts' were taken up to decolonize education. The pedagogy and evaluative methods were not considered important enough in the process of decolonization. Similarly, teacher and teacher-training remained largely driven in the colonial mode and followed Bloom's taxonomy in understanding class-room practices and management.

\section{ConCLUSION}

The above scenario where de-schooling was expected, we went ahead to achieve decolonization through re-schooling. In the process, the entire process of education remained colonial and the sub-set of curriculum was altered which was designed to the comfort of the government of the day. Therefore, every time the government changed in a newly independent nation, the emphasis was laid on re-writing history and curriculum. The rise of neo-liberal order in the last decade of the twentieth century supported the spread of right-wing ideology. The crony capitalism is bound to support populist nationalism. This had its influence on the education system which was striving to get decolonized. This further created new divides between Englishmedium schools and native-language medium schools. The quality debate in education was given a toss for outcome-based education and Ministry of Education gets a new name as Ministry of Human Resource Development.

The humans of these erstwhile colonies with mistaken modernity and misplaced idea of citizenry are now engaged to become national bigots and voters of a particular political ideology and religious-nationalism. Otherwise, the decolonized Indian education means creating a questioning spirit and questioning without fear and favour. Indoctrination in garb of education, based on one world view inhibits 
and constricts the learners in widening their horizons of understanding. Educational system should facilitate intellectual freedom which would allow students to blossom as innovative thinkers and translators. Suppression of knowledge in and through single mode and single world-view is detrimental for the present and future of India. Education is for life and thus unfolds innumerable horizons of possibilities and understandings. As a result, it must not be an imitation of the colonized educational models.

\section{Acknowledgement}

Authors are thankful to Prof Alberto Gomes, LaTrobe University, Melbourne, and Dr Jayshree Mathur, University of Delhi, Delhi, for their encouragement and guidance.

\section{REFERENCES}

Adjei, Paul B. (2007). Decolonising knowledge production: The pedagogic relevance of Gandhian Satyagraha to Schooling and Education in Ghana, Canada. Canadian Journal of Education.

Alcoff, L. M. (2014). Educating with a (De) colonial consciousness. Retrieved from: http://www.academia.edu/12894297/Educating_with_a_De_colonial_ Consciousness

Alfred, T. (2009a). Wasase: Indigenous pathways of action and freedom. Toronto, Canadá: University of Toronto Press.

Alfred,T.(2009b, November).Colonialismand statedependency.JournaldelaSante Autochtone, issue, 42-60. Retrieved from: https://www.researchgate.net/ publication/279660253_Towards_the_'tangible_unknown'Decolonization_ and_the_Indigenous_future

Bismarck, H. (2012). Defining decolonization. Britain: The British Scholar Society.

Elder, J. W. (2018). The decolonization of educational culture: The case of India. Retrieved from: http://www.jstor.org/stable/1187130

Fanon, F. (1968). The wretched of the earth. New York: Grove Press.

Pieterse, J. N. \& Parekh, B. C. (1995). The decolonization of imagination: Culture, knowledge and power. London: Atlantic Highlands, Zed books.

Sium, Desai \& Ritskes (2012). Towards the 'tangible unknown': Decolonization and the indigenous future. Decolonization: Indigeneity, Education \& Society, núm. 1. Retrieved from: https://www.researchgate.net/publication/279660253_Towards_the_'tangible_unknown'_Decolonization_and_ the_Indigenous_future

Spivak, G. C. (1988). Can the subaltern speak? Basingstoke: Macmillan. 